\title{
PENGEMBANGAN MEDIA PEMBELAJARAN BIOLOGI MELALUI PEMANFAATAN BARANG BEKAS DI SMP AL-ISLAM WAY JEPARA
}

\author{
Sulis Anjarwati ${ }^{1}$ \\ Kusuma Wardany ${ }^{2}$ \\ 1,2) Universitas Nahdlatul Ulama Lampung \\ E-mail: ${ }^{1}$ sulis.anjarwati.sa@gmail.com, ${ }^{2}$ kusuma.wardany@ymail.com
}

\begin{abstract}
This study aims to produce products in the form of biology learning media from used goods that are valid, practical, and effective for use in learning biology on the digestive system material in class VIII. This research is a Research and Development $(R \& D)$ type regarding the ADDIE development model which includes five stages, namely analysis, design, development, implementation, evaluation. The research subjects were students of class VIII SMP Al-Islam Way Jepara. The research instrument was a validation sheet to obtain product validity data, student response questionnaires to obtain product practicality data, and test questions and student response questionnaires to obtain product effectiveness data. The data obtained with validated instruments were then analyzed using descriptive statistical analysis. Based on the results of the validator's assessment, the media developed was in a very valid category with an average value of 3.8. Then, the results of students' responses related to the practicality of the media were in the high category with an average value of student responses of 4.17. Furthermore, based on the results of tests and student response questionnaires, the level of effectiveness of learning media was in the high category with an average score of 85.6, and $90 \%$ of students reached a complete score
\end{abstract}

Kata kunci: media pembelajaran, biologi, barang bekas

\section{PENDAHULUAN}

Pendidikan ialah sektor penting dalam meningkatkan kualitas sumber daya manusia. Pendidikan merupakan jalur strategis, guna menciptakan individuindividu penerus suatu bangsa yang cerdas, berakhlak dan tentunya berkualitas agar dapat membangun dan memajukan negaranya berlandaskan bekal ilmu yang telah mereka peroleh. Keberhasilan pendidikan di suatu negara menjadi salah satu indikator dalam mengukur majunya suatu Negara. Sebaliknya kesuksesan suatu negara mencerminkan kesuksesan pendidikan di negara tersebut. Begitu pula di Indonesia, secara terus-menerus dilakukan pembangunan pada sektor pendidikan dalam upaya mewujudkan kesejahteraan umum dan mencerdaskan kehidupan bangsa.

Pendidikan merupakan proses pemanusiaan menuju lahirnya insan bernilai secara kemanusiaan yang dapat dilihat dari sisi pribadi, sosial, ekonomi, sebagai makhluk Tuhan, dan pemegang mandat cultural. Sehingga benar bahwa tiap orang wajib dan berhak untuk belajar atau menuntut ilmu baik dalam artian formal maupun nonformal.

Belajar adalah kegiatan individu menggunakan ranah-ranah kognitif, afektif, dan psikomotorik sehingga terjadi perubahan pada pengatahuan, keterampilan, dan sikap (Dimyati, 2013). Belajar sebagai perubahan dalam perbuatan melalui aktifitas, praktek, dan pengalaman (Hamalik, 2012). Karenanya, akan lebih efektif bila semakin banyak anggota tubuh yang terlibat dalam proses belajar.

Pembelajaran dalam artian formal di sekolah, memanfaatkan alat bantu untuk mengajar yang disebut media pembelajaran. 
Media pembelajaran adalah segala sesuatu yang digunakan untuk menyalurkan pesan serta dapat merangsang pikiran, perasaan, perhatian dan kemauan siswa sehingga dapat mendorong terjadinya proses belajar yang disengaja, bertujuan dan terkendali (Miarso, 2013). Pembuatan/produksi dan Pengembangan media pembelajaran perlu memperhatikan prinsip "VISUALS", yang merupakan singkatan dari Visible (mudah dilihat), Interesting (menarik), Simple (Sederhana), Useful (isinya berguna/bermanfaat), Accurate (benar/dapat dipertanggung jawabkan), Legitimate (masuk akal/sah), Structured (terstruktur/tersusun dengan baik) (Nurseto, 2012).

Media pembelajaran merupakan alat bantu penyalur informasi atau pesan terkait materi pembelajaran yang ingin disampaikan pendidik ke peserta didik, yang memungkinkan peserta didik melibatkan banyak panca indera anggota tubuhnya dalam proses pembelajaran. Sehingga peserta didik lebih mudah memahami dan mengingat pelajaran yang terkadang sulit untuk diajarkan oleh pendidik tanpa bantuan media.

Penggunaan media dapat mengkonkretkan keabstrakan materi pembelajaran, yang seringkali membuat proses belajar berlangsung lama dan membosankan akibat verbalisme mengajar guru. Bahan ajar guru juga dapat diperkaya dan disajikan lebih menarik dengan media, sehingga kegiatan belajar tidak merupakan uraian yang membosankan serta memusingkan peserta didik.

Biologi merupakan cabang ilmu pengetahuan alam yang ruang lingkup pembahasannya terkait dengan makhluk hidup. Materi-materi dalam mata pelajaran biologi sebagian besar membuat peserta didik berkhayal dan sulit untuk diajarkan oleh guru tanpa adanya alat bantu pembelajaran yang tepat. Penyebabnya beragam. Keberadaan objek sebagai sumber fakta yang terbatas, dapat terjadi karena objek tidak ada, kemelimpahannya tidak tepat dengan waktu belajar (musim), sulit dijangkau karena jarak, posisi atau lokasi, terlalu kecil atau terlalu besar, berbahaya bila didekati atau dilindungi. Perkembangan fisik kota sebagai salah satu cekaman antrapogenik pada tingkat komunitas mengakibatkan terjadinya pergeseran bahkan penghilangan habitat organisme, akibatnya pada daerah perkotaan objek biologi menjadi jauh dari jangkauan. Proses sulit diamati, terjadi karena terlalu cepat (reaksi metabolisme), terlalu lambat (adaptasi dan pertumbuhan), atau berada dalam sistem yang sangat kecil (sel/organel), terjadi dalam sistem makhluk hidup, dan tidak konstan (mudah dipengaruhi faktor lingkungan) (Adinugraha, 2018).

Pembelajaran biologi yang seringkali dihadapkan pada materi abstrak dan diluar pengalaman peserta didik sehari-hari, dipadu dengan banyaknya istilah-istilah ilmiah membuat materi pelajaran sulit diajarkan guru dan sulit dipahami siswa. Sehingga pembelajaran menjadi kurang efektif.

Tingkat keefektifan pembelajaran di sekolah salah satunya dipengaruhi oleh kemampuan guru menerapkan asas kekonkretan dalam mengelola proses pembelajaran. Maksudnya, guru harus mampu menjadikan apa yang diajarkannya sebagai sesuatu yang konkret (nyata) sehingga mudah dipahami oleh peserta didik. Hal yang dibutuhkan untuk mewujudkan asas kekonkretan dalam pembelajaran di sekolah adalah media pembelajaran yang tepat (Salam et al., 2019). Visualisasi lewat media pembelajaran menjadisalah satu cara yang dapat dilakukan untuk mengkonkritkan sesuatu yang abstrak.

Namun faktanya hingga saat ini masih banyak ditemui kegiatan pembelajaran biologi yang tidak didukung dengan media ajar yang memadai untuk keefektifan pembelajaran. Mahalnya biaya yang harus dikeluarkan untuk memperoleh sebuah media ajar biologi, membuat ketersediaannya di sekolah terbatas. Kalaupun tersedia media ajar biologi di 
sekolah, alasan lainnya yaitu banyak kekhawatiran oleh guru bila melibatkan media dalam pembelajaran, khawatir alat seperti tabung reaksi, mikroskop, atau yang lainnya rusak hingga butuh pertanggung jawaban. Mengajar dengan menggunakan media ajar biologi juga dianggap menyusahkan sebab perlu persiapan, sedangkan masih banyak persiapan mengajar lain yang harus diselesaikan. Kebiasaan mengajar dengan metode ceramah menjadi faktor lain yang menyebabkan guru tetap dalam zona nyaman mengajar dengan cukup berbicara. Kemudian faktor kurangnya penghargaan dari atasan menjadikan guru akhirnya tidak terpacu untuk melakukan yang lebih baik lagi seperti membuat media untuk membantu keefektifan pembelajaran.

Asih, 2015 menjabrkan pembelajaran berbasis keterampilan proses sains adalah salah satu yang berpotensi membangun kompetensi dasar skill siswa melalui pengembangan keterampilan proses sains, sikap ilmiah, dan proses konstruksi pengetahuan secara bertahap. Pembelajaran model ini juga tercakup penemuan makna (meanings), organisasi, dan struktur dari idea tau gagasan, sehingga secara bertahap siswa belajar bagaimana mengorganisasikan dan melakukan penelitian. Pengembangan media pembelajaran dengan menggunakan barang bekas ini menjadi salah satu alternatif yang dapat mengembangkan kembpuan keteramplan siswa.

Media pembelajaran biologi sebenarnya tidak harus mahal dan canggih. Hal yang harus dipertimbangkan yaitu, kemudahan penggunaannya, keefektifan media dalam menunjang tercapainya tujuan dari proses pembelajaran, serta biaya yang harus dikeluarkan. Apabila dirancang dengan baik, barang-barang tak terpakai atau barang bekas sekalipun dapat dimanfaatkan dalam pembuatan media pembelajaran biologi. Pemanfaatan barang-barang bekas sebagai media pembelajaran akan dapat meningkatkan ketrampilan meliputi pribadi kreatif, proses kreatif dan menghasilkan produk yang kreatif (Laila \& Shari, 2016). Menurut penelitian terdahulu menyatakan bahwa media barang bekas dapat meningkatkan kemampuan kreativitas anak dalam proses pembelajaran (Hanafi \& Sujarwo, 2015). Pemanfaatan media barang bekas sebagai media bahan ajar menekankan pada peran aktif siswa dalam proses pembelajaran, sehingga pembelajaran tidak hanya berfokus pada guru tetapi mampu meningkatkan kemampuan motorik halus anak melalui kelenturan jari-jemari, serta penggunaan panca indra nya. Kegiatan pembelajaran pada pemanfaatan media barang bekas ini berhasil meningkatkan kemampuan motorik halus anak (Maghfirah, 2019).

Sebagaimana tercantum dalam Peraturan Pemerintah No. 32 Pasal 26 Tahun 2013 bahwa standar kompetensi lulusan pada satuan pendidikan menengah umum bertujuan untuk meningkatkan kecerdasan, pengetahuan, kepribadian, akhlak mulia, serta keterampilan untuk hidup mandiri dan mengikuti pendidikan lebih lanjut. Berikutnya, standar kompetensi lulusan pada jenjang pendidikan tinggi bertujuan untuk mempersiapkan peserta didik menjadi anggota masyarakat yang berakhlak mulia, memiliki pengetahuan, keterampilan, kemandirian dan sikap untuk menemukan, mengembangkan, serta menerapkan ilmu, teknologi, dan seni, yang bermanfaat bagi kemanusiaan (Peraturan Pemerintah No.32, 2013)

Berdasarkan uraian sebelumnya, penulis tertarik untuk mengembangkan suatu media yang membantu dalam pemahaman konsep biologi dan memberikan contoh peduli lingkungan dengan pemanfaatan barang bekas. Sehingga penulis berinisiatif melakukan penelitian dengan judul "Pengembangan Media Pembelajaran Biologi Melalui Pemanfaatan Barang Bekas di SMP AlIslam Way Jepara." 


\section{METODE}

Jenis penelitian yang digunakan dalam penelitian ini yaitu jenis penelitian pengembangan, yang lebih dikenal dengan istilah Research \& Development (R \& D). Penelitian Pengembangan kadang kala disebut juga sebagai suatu pengembangan berbasis pada penelitian atau Researchbased Development. Pengertian penelitian pengembangan dalam buku Educational Research (Borg \& Gall, 1983) adalah suatu proses yang dipakai untuk mengembangkan dan memvalidasi produk pendidikan. Pada penelitian ini model pengembangan yang digunakan mengacu pada model ADDIE (Analysis, Design, Development, Implementation, Evaluation) yang dapat digunakan untuk berbagai macam bentuk pengembangan produk seperti model pembelajaran, strategi pembelajaran, metode pembelajaran, media dan bahan ajar. Tahap-tahap pengembangan media ajar dapat diuraikan sebagai berikut:

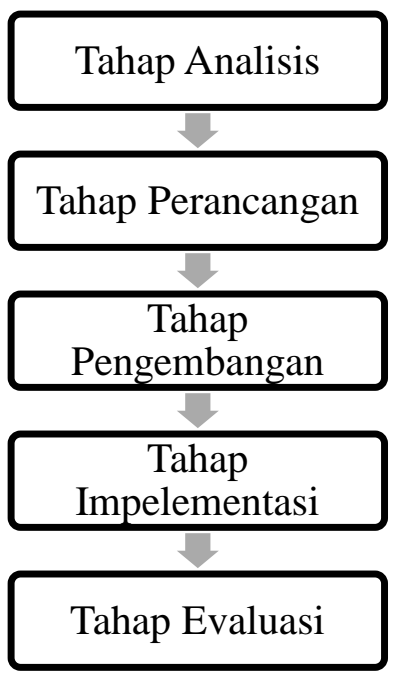

Diagram 1. Tahap-tahap Pengembangan Media Ajar

Lokasi penelitian yaitu di SMP AlIslam Way Jepara, sedangkan subjek uji coba produk yaitu siswa kelas VIII yang berjumlah 20 orang. Pemilihan lokasi dan subjek penelitian didasari pada kecenderungan karakteristik peserta didik yang tergolong aktif dalam kegiatan pembelajaran yang tersuguh menarik oleh guru, yang mendorong guru untuk selalu berusaha membuat kegiatan pembelajaran menarik. Berdasarkan hal di atas, peneliti tertantang membuat kreasi produk baru yang inovatif di lokasi penelitian tersebut, serta sebagai salah satu solusi yang membantu guru dalam mengajar dengan cara yang menarik menyenangkan dan inovatif.

Instrumen Penelitian berupa lembar validasi, angket, dan butir tes. Teknik pengumpulan data berupa data uji kevalidan, data uji kepraktisan, dan data uji keefektifan. Teknik analisis data berupa analisis data kevalidan, analisis data kepraktisan, dan analisis data keefektifan.

\section{HASIL}

Tabel 1. Hasil validasi media

\begin{tabular}{|c|l|c|c|c|c|}
\hline \multirow{2}{*}{ No. } & $\begin{array}{l}\text { Aspek } \\
\text { Penilaian }\end{array}$ & V.1 & V.2 & V.3 & $\begin{array}{c}\text { Rata- } \\
\text { rata }\end{array}$ \\
\cline { 2 - 5 } A & Tampilan Media & \multicolumn{2}{|l|}{} \\
\hline \multirow{2}{*}{} & $\begin{array}{l}\text { 1. } \\
\text { Tampilan } \\
\text { media } \\
\text { model } \\
\text { tubuh } \\
\text { manusia } \\
\text { menarik }\end{array}$ & 4 & 4 & 3 & $\mathbf{3 , 7}$ \\
\hline & $\begin{array}{l}\text { 2. } \\
\text { Tampilan } \\
\text { media } \\
\text { model } \\
\text { tubuh } \\
\text { manusia } \\
\text { jelas }\end{array}$ & 4 & 4 & 4 & $\mathbf{4}$ \\
\hline $\begin{array}{l}3 . \\
\text { Komponen } \\
\text { model } \\
\text { organ } \\
\text { tubuh pada } \\
\text { media } \\
\text { menarik }\end{array}$ & 3 & 4 & 3 & $\mathbf{3 , 3}$ \\
\hline $\begin{array}{l}\text { 4. } \\
\text { Komponen } \\
\text { model } \\
\text { organ } \\
\text { tubuh pada } \\
\text { media jelas }\end{array}$ & 4 & 4 & 3 & $\mathbf{3 , 7}$ \\
\hline
\end{tabular}

Keterangan nilai :

$3,5 \leq \mathrm{V} \leq 4,0:$ Sangat valid

$2,5 \leq \mathrm{V}<3,5:$ Valid

$1,5 \leq \mathrm{V}<2,5$ : Cukup valid

$0 \leq \mathrm{V}<1,5$ : Tidak valid 
1. Tingkat Kepraktisan Media

Pembelajaran

Kepraktisan media pembelajaran yang telah dikembangkan diukur menggunakan instrumen penelitian berupa angket respon peserta didik.

Tabel 2. Hasil Respon Peserta Didik

\begin{tabular}{|c|c|c|c|c|c|c|c|}
\hline \multirow{2}{*}{ No. } & \multirow{2}{*}{ Pernyataan } & \multicolumn{5}{|c|}{ Skor Penilaian } & \multirow[t]{2}{*}{ Rata-rata } \\
\hline & & 1 & 2 & 3 & 4 & 5 & \\
\hline 1 & $\begin{array}{l}\text { Saya merasa media } \\
\text { yang digunakan } \\
\text { kreatif memanfaatkan } \\
\text { barang bekas. }\end{array}$ & & & & 4 & 16 & 4,80 \\
\hline 2 & $\begin{array}{l}\text { Saya tertarik dengan } \\
\text { media ajar yang } \\
\text { digunakan sebab } \\
\text { tampilannyaunik. }\end{array}$ & & & & 5 & 15 & 4,75 \\
\hline 3 & $\begin{array}{l}\text { Gambar yang ada } \\
\text { pada media jelasdan } \\
\text { tidak kabur. }\end{array}$ & & & 3 & 11 & 6 & 4,15 \\
\hline 4 & $\begin{array}{l}\text { Tampilan model } \\
\text { organ tubuh manusia } \\
\text { pada media jelas dan } \\
\text { mudah dipahami. }\end{array}$ & & & 2 & 11 & 7 & 4,25 \\
\hline 5 & $\begin{array}{l}\text { Model organ tubuh } \\
\text { pada media } \\
\text { menyerupai aslinya. }\end{array}$ & & & 1 & 12 & 7 & 4,30 \\
\hline 6 & $\begin{array}{l}\text { Susunan model } \\
\text { organ-organ tubuh } \\
\text { pada media sesuai } \\
\text { dengan materi } \\
\text { konsep. }\end{array}$ & & & & 14 & 6 & 4,30 \\
\hline 7 & $\begin{array}{l}\text { Saya merasa sangat } \\
\text { kesulitan } \\
\text { menggunakan media } \\
\text { ajar berbahanbarang } \\
\text { bekas. }\end{array}$ & & & 2 & 16 & 2 & 4,00 \\
\hline 8 & $\begin{array}{l}\text { Saya mampu } \\
\text { menggunakan media } \\
\text { ajar dengan benar. }\end{array}$ & & & 6 & 13 & 1 & 3,75 \\
\hline 9 & $\begin{array}{l}\text { Media menunjang } \\
\text { materi sebab dapat } \\
\text { membantu saya } \\
\text { memahamikonsep } \\
\text { biologi dengan } \\
\text { benar. }\end{array}$ & & & 2 & 14 & 4 & 4,10 \\
\hline
\end{tabular}

\begin{tabular}{|c|l|l|l|l|l|l|}
\hline 10 & $\begin{array}{l}\text { Media pembelajaran } \\
\text { mampu membantu } \\
\text { mengkongkretkan } \\
\text { materiyang abstrak. }\end{array}$ & & 5 & 11 & 4 & 3,95 \\
\hline 11 & $\begin{array}{l}\text { Saya lebih cepat } \\
\text { memahami/menging } \\
\text { at materi berkat } \\
\text { penggunaan media } \\
\text { dalam pembelajaran } \\
\text { biologi. }\end{array}$ \\
\hline 2 & $\begin{array}{l}\text { Media yang } \\
\text { digunakan } \\
\text { membantudalam } \\
\text { pelaksanaan } \\
\text { kegiatan } \\
\text { pembelajaran } \\
\text { dengan tepat waktu. }\end{array}$ & 6 & 14 & 17 & 1 & 3,95 \\
\hline Rata-rata Total & & & & & & \\
\hline
\end{tabular}

Keterangan nilai :

$0,0 \leq \mathrm{M}<1,0:$ Sangat rendah1,0 $\leq$

$\mathrm{M}<2,0$ : Rendah

$2,0 \leq \mathrm{M}<3,0:$ Sedang3,0 $\leq \mathrm{M}<4,0$

: Tinggi

$$
4,0 \leq \mathrm{M} \leq 5,0 \text { : Sangat tinggi }
$$

\section{Tingkat Keefektifan Media}

Pembelajaran

Data terkait keefektifan media diperoleh pada tahap evaluasi. Tingkat keefektifan media diukur dengan menggunakan instrumen berupa tes dan angket respon peserta didik.

a. Tes

Instrumen tes digunakan untuk mengukur tingkat penguasaan peserta didik akan materi yang telah diajarkan dengan menggunakan media pemmbelajaran. Data hasil tes peserta didik dapat dilihat pada tabel 4.4 berikut:

Tabel 3. Hasil Tes Peserta Didik

\begin{tabular}{|c|c|c|}
\hline No. & Siswa & Nilai \\
\hline 1 & $X$ & 88 \\
\hline 2 & $X$ & 92 \\
\hline 3 & $X$ & 84 \\
\hline 4 & $X$ & 80 \\
\hline 5 & $X$ & 92 \\
\hline
\end{tabular}




\begin{tabular}{|c|c|c|}
\hline 6 & $X$ & 80 \\
\hline 7 & $X$ & 96 \\
\hline 8 & $X$ & 88 \\
\hline 9 & $X$ & 84 \\
\hline 10 & $X$ & 84 \\
\hline 11 & $X$ & 72 \\
\hline 12 & $X$ & 80 \\
\hline 13 & $\mathrm{X}$ & 92 \\
\hline 14 & $X$ & 84 \\
\hline 15 & $\mathrm{X}$ & 88 \\
\hline 16 & $\mathrm{X}$ & 84 \\
\hline 17 & $X$ & 96 \\
\hline 18 & $X$ & 68 \\
\hline 19 & $X$ & 84 \\
\hline 20 & $\mathrm{X}$ & 96 \\
\hline \multicolumn{2}{|c|}{ Rata-rata } & 85,6 \\
\hline
\end{tabular}

\section{b. Respon Peserta Didik}

Respon peserta didik juga dibutuhkan dalam mengukur seberapa efektif media pembelajaran yang digunakan. Data hasil respon peserta didik dapat dilihat pada tabel 4 berikut:

\section{Tabel 4. Hasil Respon Peserta Didik}

\begin{tabular}{|c|c|c|c|c|c|c|c|}
\hline \multirow{2}{*}{ No. } & \multirow{2}{*}{ Pernyataan } & \multicolumn{5}{|c|}{ Skor Penilaian } & \multirow{2}{*}{$\begin{array}{c}\text { Rata- } \\
\text { rata }\end{array}$} \\
\hline & & 1 & 2 & 3 & 4 & 5 & \\
\hline 1. & $\begin{array}{l}\text { Saya tertarik } \\
\text { belajar dengan } \\
\text { menggunakan } \\
\text { media ajar } \\
\text { biologi. }\end{array}$ & & & & 14 & 6 & 4,30 \\
\hline 2. & $\begin{array}{l}\text { Saya lebih } \\
\text { bersemangat } \\
\text { untuk belajar } \\
\text { dengan adanya } \\
\text { media ajar yang } \\
\text { digunakan. }\end{array}$ & & & 1 & 12 & 7 & 4,30 \\
\hline 3. & $\mid \begin{array}{lr}\text { Saya } & \text { terdorong } \\
\text { mempelajari } \\
\text { materi } & \text { lebih } \\
\text { dalam } & \text { sebab } \\
\text { media } & \text { membuat } \\
\text { kegiatan } & \text { belajar } \\
\text { menyenangkan. }\end{array}$ & & & 1 & 11 & 8 & 4,35 \\
\hline
\end{tabular}

\begin{tabular}{|c|c|c|c|c|c|}
\hline 4. & $\begin{array}{l}\text { Saya merasa } \\
\text { ingin tahu } \\
\text { mengenai materi } \\
\text { yang diajarkan } \\
\text { sebab mediaajar } \\
\text { yang digunakan } \\
\text { menarik. }\end{array}$ & & 7 & 13 & 4,65 \\
\hline 5. & $\begin{array}{l}\text { Materi yang saya } \\
\text { pelajari berkaitan } \\
\text { dengan media } \\
\text { ajar yang } \\
\text { digunakan. }\end{array}$ & & 3 & 17 & 4,85 \\
\hline 6. & $\begin{array}{l}\text { Saya tidak bosan } \\
\text { saat belajar } \\
\text { sebabmedia } \\
\text { membuat } \\
\text { pelajaran } \\
\text { menarik. }\end{array}$ & & 1 & 19 & 4,95 \\
\hline 7. & \begin{tabular}{|l|} 
Saya merasa \\
belajar dengan \\
menggunakan \\
media \\
memberikan \\
pengalaman \\
belajar baru yang \\
berkesan. \\
\end{tabular} & & 2 & 18 & 4,90 \\
\hline 8. & $\begin{array}{l}\text { Saya merasa } \\
\text { belajar biologi } \\
\text { membosankan } \\
\text { sebab metode } \\
\text { mengajar guru } \\
\text { biasa saja. } \\
\end{array}$ & & 8 & 12 & 4,60 \\
\hline 9. & $\begin{array}{l}\text { Saya } \\
\text { terbantu/dimuda } \\
\text { hkan dalam } \\
\text { belajar dengan } \\
\text { adanya media. }\end{array}$ & 2 & 8 & 10 & 4,40 \\
\hline 10. & $\begin{array}{l}\text { Saya lebih dapat } \\
\text { memahami dan } \\
\text { mengingat } \\
\text { materi pelajaran } \\
\text { dengan } \\
\text { menggunakan } \\
\text { media ajar. } \\
\end{array}$ & 4 & 7 & 9 & 4,25 \\
\hline 11. & $\begin{array}{l}\text { Saya sulit } \\
\text { mempelajari } \\
\text { materi sebab } \\
\text { penyajiannya } \\
\text { tidak menarik. }\end{array}$ & & 5 & 15 & 4,75 \\
\hline
\end{tabular}




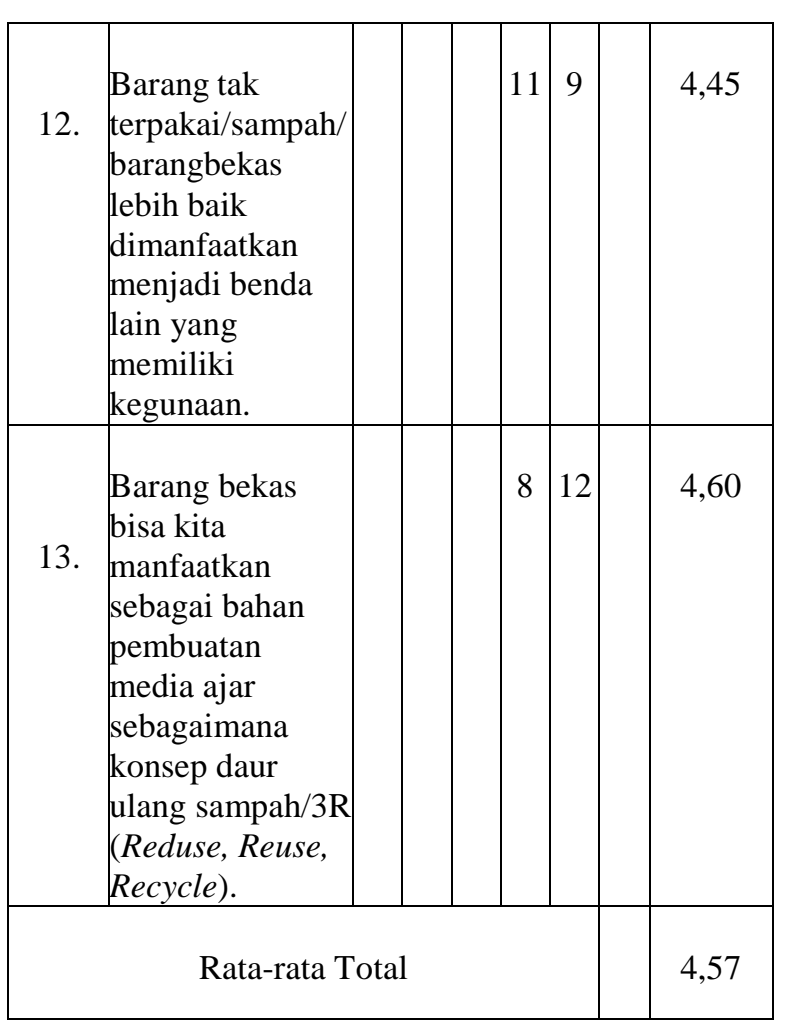

Keterangan nilai :

$0,0 \leq \mathrm{M}<1,0:$ Sangat rendah $1,0 \leq$

$\mathrm{M}<2,0:$ Rendah

$2,0 \leq \mathrm{M}<3,0$ : Sedang $3,0 \leq \mathrm{M}<$

4,0 : Tinggi

$4,0 \leq \mathrm{M} \leq 5,0:$ Sangat tinggi

\section{PEMBAHASAN}

1. Pengembangan Media Pembelajaran Biologi

Peneliti mengikuti prosedur pengembangan media ajar dengan mengacu pada model pengembangan ADDIE yang terdiri atas lima tahapan (analysis, design, development, implementation, and evaluation), untuk mengembangkan media pembelajaran biologi berbahan barang bekas.

a. Analisis (Analysis)

Tahap ini merupakan langkah awal penelitian pengembangan. Pada tahapini dilakukan analisis pendahuluan yang secara umum meliputi analisis kebutuhan, analisis peserta didik serta analisis materi.

1) Analisis Kebutuhan

Pada tahap awal penelitian, peneliti terlebih dahulu berkunjung beberapa kali di sekolah yang menjadi lokasi penelitian yaitu SMP Al-Islam Way Jepara. Kelas yang dijadikan subyek penelitian adalah kelas VIII. Kunjungan dilakukan dalam rangka menganalisis kebutuhan akan media yang akan dikembangkan dalam meningkatkan pemahaman dan hasil belajar peserta didik, serta mengumpulkan informasi lainnya terkait karakteristik peserta didik serta analisis materi pelajaran yang diperlukan untuk menetapkan media pembelajaran yang akan dikembangkan nantinya. Dari hasil investigasi, diketahui bahwa kondisi di lapangan menunjukkan tersedianya media pembelajaran seperti media cetak (buku teks) dan beberapa alat peraga model tubuh manusia serta media berbasis teknologi seperti penggunaan LCD pada kesempatan-kesempatan tertentu. Peserta didik tergolong cukup aktif dan fokus perhatiannya bergantung pada menarik tidaknya kegiatan pembelajaran.

\section{2) Analisis Peserta Didik}

Analisis peserta didik dilakukan untuk mengetahui karakteristik peserta didik. Informasi mengenai karakteristik peserta didik dibutuhkan guna menyesuaikan rancangan media yang akan dikembangkan dengan karakteristik peserta didik yang akan menggunakannya. Pada tahap analisis peserta didik, peneliti mengumpulkan informasi dari mengamati langsung peserta didik kelas VIII dan dari guru yang bersangkutan.

b. Perancangan (Design)

Dalam membuat rancangan media, peneliti mengumpulkan bahan utama kardus dahulu serta menyiapkan atau melengkapi alat-alat dan bahan yang dibutuhkan. Kardus yang digunakan adalah kardus bekas minuman kemasan dan bekas mie instan yang ukuran panjang dan lebarnya tidak terlalu kecil, semakin 
besar ukurannya semakin baik. Alatalat yang digunakan meliputi gunting, cutter, penggaris besi, pensil, dan pensil warna. Bahan-bahan yang digunakan meliputi kardus bekas, kertas coklat pembungkus nasi, dan lem kertas.

Setelah alat dan bahan-bahan yang dibutuhkan telah tersedia, peneliti mulai merancang seperti apa bentuk media yang akan dibuat. Ide awal rancangan produk yaitu berupa media dari kardus yang dibentuk menyerupai bentuk siluet tubuh manusiadari kepala hingga pangkal paha. Namun untuk membuat bentuk siluet tubuh dari kepala hingga pangkal paha tersebut akan dibutuhkan kardus yang panjang dan lebar seperti ukuran tubuh manusia dari kepala hingga pangkal paha pula. Sebab tidak rapi bila membentuk siluet tubuh tersebut dari kardus berukuran kecil yang dihubung- hubungkan. Peneliti sulit mendapat kardus berukuran besar, selain itu bila media hanya berbentuk siluet tubuh manusia, bentuknya datar, biasa saja dan kurang menarik, sehingga peneliti memutuskan merancang media model tubuh manusia yangbervolume.

Model tubuh manusia yang dibuat dibedakan menjadi tiga bagian yaitu bagian kepala, badan, dan organ sistem pencernaan. Pada tahap design ini, peneliti menggambar langsung pada kardus pola atau sketsa bagianbagian kecil yang menyusun model kepala media tersebut.

Selain perancangan media, dilakukan pula penyusunan instrumen penelitian untuk menguji kevalidan, kepraktisan serta keefektifan dari media yang dikembangkan. Rancangan media yang telah dibuat pada tahap ini akan dikembangkan untuk menjadiprototype 1 yang kemudian akan divalidasi oleh dua orang validator ahli, dan seorang praktisi pendidikan.

\section{c. Pengembangan (Development) Rancangan media kemudian dibuat}

dan dikembangkan untuk mendapatkan prototype I media. Pola tiap bagian penyusun model kepala media digunting. Bagian- bagian kardus yang telah digunting sesuai pola dirangkai satu sama lain hinggaberbentuk model kepala manusia. Perangkaian ini bertujuan untuk memudahkan dalam menentukan ukuran bagian model tubuh serta bagian model organ sistem pencernaan yang akan dibuat, selanjutnya dibuatkan pola untuk bagian-bagian penyusun model tubuh media, yang kemudian digunting dan dirangkai bersama model kepala manusia dari media. Khusus model organ tubuh, peneliti menggambar dengan pensil warna langsung pada kertas coklat bungkus nasi (bukan berupa pola) untuk menghasilkan warna yang hampir mirip dengan organ tubuh yang asli. Selanjutnya kertas digunting sesuai gambar dan ditempel di kardus yang telah digunting mengikuti pola gambar. Media yang telah dibuat dan dikembangkan akan dinilai oleh para ahli/validator, kegiatan ini disebut validasi prototype 1 . Selanjutnya hasil validasi beserta saransaran dari para validator dijadikan acuan dalam merevisi media yang dikembangkan.

\section{d. Evaluasi (Evaluation)}

Setelah media diuji cobakan dalam situasi nyata pembelajaran di kelas, dilakukanlah tahap terakhir dari pengembangan model ADDIE yakni evaluasi. Dalam penelitian ini evaluasi dilakukan untuk memperoleh data mengenai keefektifan media. Evaluasi diadakan setelah kegiatan belajar mengajar selesai, yaitu dengan membagikaninstrumen evaluasi berupa soal tes dan angket. Soal tes diberikan untuk mengetahui apakah media benar dapat membantu memberikan pemahaman yang lebih baik pada peserta didik atau tidak. Soal tes berjumlah 25 soal dalam bentuk pilihan 
ganda dengan tipe kognitif yang berbeda-beda, mulai dari $\mathrm{C} 1$ (pengetahuan), C2 (pemahaman), C3 (Aplikasi) hingga $\mathrm{C} 4$ (analisis). Butir soal dengan tipe kognitif $\mathrm{C} 1$ (pengetahuan) sebanyak enam soal, untuk C2 (pemahaman) sebanyak dua belas soal, untuk C3 (Aplikasi) sebanyak dua soal, dan terakhir untuk C4 (analisis) sebanyak lima soal.

Kemudian untuk mengetahui bagaimana sebenarnya pendapat siswa mengenai media yang digunakan dalam pembelajaran, dibagikan pula angket respon peserta didik setelah kegiatan pembelajaran usai. Angket yang dibagikan terdiri atas dua variabel yakni keefektifan media pembelajaran serta kepraktisan media pembelajaran. Variabel kepraktisan media meliputi tiga faktor, pertama tampilan media, kedua kegunaan media, dan terakhir keefisienan. Sedangkan variabel keefektifan meliputi empat faktor yaitu minat dan motivasi belajar, relevansi media dengan materi ajar, kualitas kegiatan belajar mengajar, serta kesadaran lingkungan. keseluruhan faktor yang ingin diukur untuk mengetahui kepraktisan dan keefektifan media tersebut dijabarkan kedalam duapuluh lima item pernyatan pada angket.

2. Tingkat Kevalidan

Setelah dianalisis, diperoleh ratarata hasil penilaian dari para validator untuk keseluruhan aspek yakni 3,8. Data tersebut menunjukkan bahwa media pembelajaran berbahan barang bekas yang telah dikembangkan berada dalam kategori sangat valid. Media yang dikembangkan telah berdasarkan landasan teori yang kuat sehingga media telah sahih dan layak untuk digunakan.

\section{Tingkat Kepraktisan}

Rata-rata hasil respon peserta didik terhadap kepraktisan media pembelajaran yang diperoleh dari angket adalah 4,17. Nilai tersebut berada dalam kategori tingkat kepraktisan tinggi yang menunjukkan bahwa berdasarkan respon peserta didik, media pembelajaran yang telah dikembangkan dinyatakan dapat digunakan dalam proses pembelajaran. Media dapat dengan mudah diangkat dan dibawa berpindah dari satu tempat ke tempat yang lain. Selain itu baik guru maupun peserta didik dapat menggunakan media untuk mempelajari materi terkait sistem pencernaan. Hal ini sesui dengan hasil penelitian terdahulu yaitu media pembelajaran yang berhasil dikembangkan telah memenuhi syarat kepraktisan ber- dasarkan rata-rata nilai respon guru (terkategori positif) dan respon siswa (terkategori sangat positif) (Yudasmara \& Purnami, 2015).

\section{Tingkat Keefektifan}

Setelah merealisasikan media pada kondisi nyata pembelajaran di kelas, dilakukanlah evaluasi untuk mengukur tingkat keefektifan media pembelajarn yang telah dikembangkan. Berdasarkan hasil evaluasi dengan menggunakan tes, sebesar $90 \%$ peserta didik mencapai nilai tuntas dengan nilai rata-rata sebesar 85,6. Nilai tersebut menunjukkan bahwa pembelajaran berhasil secara klasikal. Selain itu, hasil respon peserta didik dari angket yang disebarkan juga berada pada kategori tingkat keefektifan tinggi yakni rata-rata 4,57. Keefektifan media menunjukkan bahwa dalam kegiatan pembelajaran, media dapat memberikan pengaruh yang baik pada pemahaman peserta didik mengenai materi sistem pencernaan dan pemahaman lingkungan terkait pemanfaatan barang bekas di sekolah. Media pembelajaran membantu guru dalam menyampaikan materi ajar dengan cara yang menarik, sehingga peserta didik tertarik untuk 
ikut berperan aktif dalam pembelajaran yang akhirnya membuat pembelajaran menjadi efektif. Sebagaimana Chamany berpendapat bahwa pembelajaran yang baik mampu menyajikan konsep-konsep yang dipelajari menjadi contoh yang nyata tentang keadaan atau fenomena pada lingkungan sekitar (Chamany dkk., 2008). Hal tersebut dikuatkan oleh Edward L. Deci, dkk., bahwa guru harus menciptakan suasana belajar yang mendukung keterlibatan peserta didik dalam proses pembelajaran (Jang dkk., 2010).

5. Keunggulan dan Keterbatasan Produk Beberapa keunggulan dari media berbahan barang bekas sebagai berikut:

a. Biaya produksi media pembelajaran tidak mahal;

b. Alat dan bahan pembuatan media mudah didapatkan;

c. Media dapat dibongkar pasang sehingga memudahkan untuk dibawa dan digunakan dalam mengajar banyak peserta didik sebab dapat dipisahkan.

Beberapa keterbatasan dari media berbahan barang bekas sebagai berikut:

a. Media terbuat dari kardus sehingga tidak tahan air;

b. Organ-organ pada media hanya berupa gambar belum bervolume sebagaimanaorgan tubuh sebenarnya.

\section{KESIMPULAN}

1. Media pembelajaran berbahan barang bekas pada materi sistem pencernaan dikembangkan dengan mengacu pada model pengembangan ADDIE yang meliputi analysis (analisis), design (perancangan), (pengembangan), development (implementasi), and evaluation (evaluasi).

2. Tingkat kevalidan media pembelajaran berbahan barang bekas dikategorikan sangat valid dengan nilai rata-rata kevalidan $3,8(3,5 \leq \mathrm{V} \leq 4,0)$.

3. Tingkat kepraktisan media pembelajaran berbahan barang bekas dikategorikan sangat tinggi dengan nilai rata-rata kepraktisan $4,17(4,0 \leq \mathrm{Va}$ $\leq 5,0)$.

4. Tingkat keefektifan media pembelajaran berbahan barang bekas dikategorikan sangat efektif dimana 90\% peserta didik memperoleh nilai tuntas dengan nilai rata-rata peserta didik 85,6, serta nilai rata-rata respon peserta didik yang berada pada kategori $4,57(4,0 \leq \mathrm{Va} \leq 5,0)$.

\section{DAFTAR RUJUKAN}

Adinugraha, F. 2018. Media Pembelajaran Biologi Berbasis Ecopreneurship. Formatif: Jurnal Ilmiah Pendidikan MIPA. https://doi.org/10.30998/formatif.v $7 \mathrm{i} 3.2233$

Asih, T. 2015. Pengembangan Model Panduan Pembelajaran Keterampilan Proses Sains Biologi SMA/MA. Jurnal Pendidikan Biologi Bioedukasi Vol. 6 No. 1 Mei 2015. Lampung: Universitas Muhammadiyah Metro.

Borg, W. ., \& Gall, M. . 1983. Educational Research an Introduction fourth edition. Longman Inc.

Chamany, K., Allen, D., \& Tanner, K. 2008. Making biology learning relevant to students: Integrating people, history, and context into college biology teaching. In $C B E$ Life Sciences Education. https://doi.org/10.1187/cbe.08-060029

Dimyati, M. dan. 2013. Model-model pengajaran dan pembelajaran. Teaching and Educations.

Hamalik, P. D. O. 2012. Belajar dan Mengajar. Education.

Hanafi, S. H., \& Sujarwo, S. 2015. Upaya meningkatkan kreativitas anak dengan memanfaatkan media barang bekas di TK Kota Bima. 
Jurnal Pendidikan Dan

Pemberdayaan Masyarakat. https://doi.org/10.21831/jppm.v2i2. 6360

Jang, H., Reeve, J., \& Deci, E. L. 2010. Engaging Students in Learning Activities: It is Not Autonomy Support or Structure but Autonomy Support and Structure. Journal of Educational Psychology. https://doi.org/10.1037/a0019682

Laila, A., \& Shari, S. 2016. Peningkatan kreativitas mahasiswa dalam pemanfaatan barang-barang bekas pada mata kuliah media pembelajaran. Jurnal Pendidikan Dasar Nusantara.

Maghfirah, S. 2019. Pemanfaatan Barang Bekas dalam Meningkatkan Kemampuan Motorik Halus Anak. Atfālunā: Journal of Islamic Early Childhood Education. https://doi.org/10.32505/atfaluna.v 2i1.938

Miarso, Y. 2013. Menyemai Benih Teknologi Pendidikan. In Computer.

Nurseto, T. 2012. Membuat Media
Pembelajaran yang Menarik. Jurnal Ekonomi Dan Pendidikan. https://doi.org/10.21831/jep.v8i1.7 06

Peraturan Pemerintah No.32. 2013. Peraturan Pemerintah Republik Indonesia Nomor 32 Tahun 2013 Tentang Standar Nasional Pendidikan. Sekretariat Negara.

Salam, N., Safei, \& Jamilah. 2019. Pengembangan Media Pembelajaran Ular Tangga Pada Materi Sistem Saraf. Al-Ahya.

Yudasmara, G. A., \& Purnami, D. 2015. Pengembangan Media Pembelajaran Belajar Siswa SMP. Jurnal Pendidikan Dan Pengajaran. 